\title{
THE EFFECT OF INDIRECT PAYMENT TO EMPLOYEES LOYALTY IN BANK PERKREDITAN SADYHA MUKTI PARAMA
}

\author{
Lily Hendrasti Novadjaja, M.Abdi Dzil Ikhram Wijaya \\ Faculty of Economics and Business Universitas Brawijaya \\ Email: lily@ub.ac.id
}

\begin{abstract}
This study aims to determine several dimensions of indirect compensation of on the job break, hazard protection, service programs, legal payments and health insurance is a dimension of indirect compensationThe population in the study were all employees of Bank Perkreditan Rakyat (BPR) Sadyha Mukti Parama, there are 16 employees. This study used questionnaire to be answered the analysis and the data analysis used Partial Least Square (PLS). Based on the analysis of data in this study show that the compensation indirect positive effect on employee loyalty. Substantially the results showed that the strongest indicator that supports variable indirect compensation to the loyalty of the employees are the programs of the employees. The programs of employees in the opinion of the respondents is paramount, this is because employees of Bank Perkreditan Rakyat (BPR) Sadyha Mukti Parama already find facilities such as a break on the Job, protection against danger, service programs, payment of legal and health insurance was considered enough to meet the needs. This study provides some theoretical implications indicate that the compensation does not directly provide a significant impact on employee loyalty Bank Perkreditan Rakyat (BPR) Sadyha Parama Mukti and the results show that the indirect compensation variable dimensions are on the job break, hazard protection, service programs, legal payments and health insurance have a significant effect on employee loyalty.
\end{abstract}

Keywords: indirect payment, loyalty, employee

\section{INTRODUCTION}

Management is a process undertaken to realize the objectives of the organization through a series of activities such as planning, organizing, directing, and controlling the people and resources of the organization (Dessler, 2006). Resources as the main element of a very large company in order to achieve the goals set by the company. The company will not be able to work efficiently and effectively if it is not supported by the human resources that have ability. This means that human resources is very important for the success of a company, big or small, regardless of the type of industry (Schuler, 1997).

Recognizing the importance of human resources for the survival and progress of the company, then the company should give special attention to employees who are no longer seen as a factor of production but as a partner (Saydam, 2000). To encourage employee morale is need for mutually beneficial working 
relationship between employees with the company. Employee giving a good performance for the company while the company appreciated it with welfare with an adequate compensation according to the workload to maintain loyalty, As stated by Filippo (1984) stated that human resource management is the process of planning, organizing, directing and controlling of supplying power employment, development, maintenance and integration compensation termination of employment with a view to achieve the goals or objectives of individuals, organizations, and society, one of the key points above are compensated.

Dessler (2006) States that compensation has two components, namely direct payments (direct financial payment) in the form of wages, salaries, incentives, commissions, and bonuses. As well as payments indirectly (indirect payment) in the form of benefits such as insurance and holidays. In the study one of the variables in question is the loyalty according to WJS. Poerwadarminta cited by Krishna (2012) on the above understanding, it has concluded that a tendency of employees to move to another company. When working in a company, and the company tried to meet adequate facilities and received by employees, the employee loyalty to the company will be even greater, then the resulting impulse which can lead to more active employees.

The facilities received by employees so that employees want to work as best as possible and remain loyal to the company, the company should provide appropriate rewards to its employees. To that end, according
Nitisemito (1991) suggests several ways companies provide facilities such as salary, spiritual needs, working environment, appropriate job placement, self-actualization, security, foster loyalty, occasionally involving employees in some of the negotiations, and provide a pleasant facility.

The importance of human resource management in managing one administration employee compensation program in an effort to increase loyalty. The source of employee dissatisfaction is divided into non-material and material that the material could be caused by low wages and minimum facilities. For non-material appreciation as a man with trying to assign roles and so on (Nitisemito, 1991).

Competition agencies also quite tight enough to affect the limitations of the human factor is very important for the company, this is related to the management of human resources well be limited. Limited in question is the company's ability to determine the most effective way in loyalty to employees is limited. One way to increase employee loyalty by watching compensation. Compensation is divided into two: direct compensation and indirect compensation (fringe benefits), direct compensation is itself a base wages and other variables while indirect compensation with a different type than the direct compensation that already has a standard that is clear, both private and governmental.

Indirect compensation is one of the operational functions of the scope of maintenance of human resources to maintain and grow the willingness of employees in a company. Indirect 
compensation is compensation in the form of providing benefits packages and organizing employee service programs aimed at retaining organizational employees in the long run. (Handoko, 2010). Indirect compensation has the goal of creating a willingness to work for a long period of time. Benefits and objectives of the existence of indirect compensation according to (Handoko, 2010), namely making an employee recruitment effective, improve morale, employee loyalty and attachment to the company, reducing the influence of trade unions and the threat of government intervention. Based on the above explaination, researchers choose the object carried on BPR Sadyha Mukti Parama due Bank Perkreditan Rakyat (BPR) is one of the important backbone of national development.

The objective of thisstudy is to find out how much the relationship between compensation indirectly given by the loyalty of employees working in the office of Bank Perkreditan Rakyat (BPR) Sadyha Parama Mukti. Indirect payment referred to herein include breaks on the job, protection against danger, service programs, legal and health insurance payments. In addition, this study aims to determine whether the type of indirect compensation significantly influence employee loyalty Bank Perkreditan Rakyat (BPR) Sadyha Parama Mukti.

\section{LITERATURE REVIEW}

The previous study of Kasper, et al. (2012) conducted a study to analyze how much influence the fringe benefits provided by the company to turn over employees in various agencies and companies, namely automotive, chemical, industrial, electronics, and banking. The study was conducted in the city of Shanghai, China. From the results of research conducted by 14 managers ( 8 women and 6 men) with the interview method is known that the fringe benefits given by the company that has been mentioned is the main motivation but it is also influenced by other factors, namely: career opportunity, income, working tasks, company culture, working condition, becoming an entrepreneur and job stress and it is a lesson learned for the company amid the competition how to defend employees to remain loyal.

Past research has subsequently contained in the journal conducted by Heshizer (1994) analyze how much the influence of fringe benefits provided by the company against three variables: turnover, job satisfaction, and commitment of employees in various agencies and companies that Hospital and Bank in town Midwestern, USA. The overall research uses quantitative methods using multiple linear regression analysis.

Furthermore, previous studies conducted by Gunawan (2011) analyze how much influence the general compensation to employee loyalty. Overall research conducted using multiple regression analysis, it is known that the compensation is still divided into two types, namely financial compensation and nonfinancial (Career and Work Environment) and generally variable compensation effect on the loyalty of the employee's performance either partially or simultaneously and 
explained that financial compensation the dominant compared to the nonfinancial compensation.

In addition, Manik (2016) explained that the optimal performance of bank employees will be able to gather employees who have the spirit of work in completing tasks and responsibilities given by the management. One of the help of the bank management in increasing the morale of their employees is to provide appropriate compensation for their employees. The study was conducted at one of the banks that hold loans with 32 employees. The results of this study found the results of the study, ability to pay, willingness to pay, demand for labor and employee organizations that are significant to compensation at the Bank.

Basically, humans work also wanted to earn money to make ends meet. For that an employee begin to appreciate the hard work and continued to show loyalty to the company and therefore the company rewards the employee performance by providing compensation. Having conformity with the views expressed Mathis and Jackson (2009) one of the ways of management to improve the performance, motivate and improve employee performance is through compensation. Ivancevich (2006) also explains that the compensation is human resource management functions associated with each type of award received by an individual for conduct organizational tasks. Compensation is a major cost in running a business for many organizations in the early $21 \mathrm{st}$ century.
Handoko (2010) states that compensation is important for employees as individuals because of the amount of compensation reflects the size of their work among the employees themselves, their families and communities. Also according to Dessler (2006) that is all forms of employee compensation payments or gifts given to employees and emerged as the employment of those employees. Meanwhile, according to Simamora (2007) includes the returnreturn compensation and financial services and benefits received by employees as part of an employment relationship. The conclusion was that the compensation was an all giving the company money in the form of direct or indirect to the employee as a remuneration for the work he has done for the company.

While Hasibuan (2010) provides a definition relating to compensation is all the income in the form of money, goods directly or indirectly received by employees as a reward for services rendered to the company. Hasibuan (2010) also mentions that the compensation is divided into two, namely: direct compensation in the form of salaries, wages and incentives; indirect compensation or employee welfare or the welfare of employees).

There are several criteria that need to be considered in the determination of the compensation policy, among others (Notoatmodjo, 2009) that is cost of living, criteria for awarding compensation cost of living that is essentially what is happening in the community inflation, meaning that even though inflation means that the cost of living increases, the 
compensation must be followed. Second criteria are productivity, increased employee productivity in the goods would affect the increase in income and the organizations concerned. Third criteria are prevailing wage scale. In general, the organization concerned may refer to the organization as a criterion for granting equitable compensation for employees. Fourth criteria are ability to pay, all organizations always take into account the amount is usually expended to pay wages or compensation of employees. And the last criteria are motivation to employees, good organization will always attract potential employees to work on it, as well as retain their employees to feel at home.

In addition, the purpose of the compensation according to Hasibuan (2012), among others is: first, cooperative ties by compensating grew a formal cooperation between the organization and employees. Second, job satisfaction by remuneration, employees will be able to meet the needs of the physical, social and selfish to gain job satisfaction and job title. Third, effective procurement, if the compensation is set large enough, procurement of qualified employees for the company will be easier. Forth, motivation, if remuneration is large enough, the manager will be easy to motivate subordinates. Fifth, stability employees with the compensation program on the principle of fair and reasonable, and external consistency commentary the stability of the employees are more secure because the relatively small turn-over. Sixth, discipline with the provision of remuneration which is big enough then the better the employee discipline. Seventh, the influence of labor unions with a good compensation program, the influence of trade unions can be avoided and employees will concentrate on his work. The last, government influence if compensation in accordance with applicable law, the government intervention can be avoided.

According to Mondy (2002), direct compensation payment means in the form of money received directly tangible employee salaries or wages, economic fringe, bonuses and commissions. Salary is the remuneration paid periodically to permanent employees as well as more definite, while wages are the remuneration paid to daily workers by referring to the treaty agreed payer, and incentive pay is an additional remuneration granted to certain employees whose achievements in on achievement standards.

Compensation have a two types, one of which is the direct compensation that has a meaning according to Handoko (2010) stated that monetary compensation or salary compensation is relatively straightforward. Simamora (2006) also explains that direct compensations were divided into two, namely financial compensation (direct finance compensations) which is a form of cash payments received by employees directly in the form of salary or wages, economic benefits, commissions and bonuses. The next type of compensation is indirect financial compensation which is a financial award that does not include direct compensation. A form of 
indirect compensation programs include employment insurance, social assistance, payment of fees for medical treatment and others leave.

Further compensation is indirect compensations, Handoko (2010) explains that the principal purpose of the giving or providing complementary compensation or can be called fringe benefits are to retain long-term employees in the organization. This complementary compensation benefits package shaped provision and delivery of employee services programs. Benefits and services is an indirect compensation because it is usually treated as an effort to create the conditions and pleasant working environment and not directly related to job performance.

Various forms of the different complementary compensation have various names in the industry, but in essence is the same that provide payments outside the salary or wages, and other benefits in an organization. Whatever the name, a program to provide supplementary compensation can be grouped into four categories. First, payment of wages to nonworking time (time-off benefits) which is a time period during which the employee did not work but still be rewarded as when the employee does not work due to illness, vacation or leave and other reasons such as pregnancy, accidents, prolonged illness. Second, economical protection against general hazards and considered by an insurance company. This insurance program can be life insurance, health insurance and accident insurance. There are also benefits that can improve the security of insurance beyond that is a guarantee of payment of wages in a certain amount during a period, pension plans, annuities, medical allowance and the formation of cooperatives or foundations that manage employee credit. Third, programs of service of employees (facilities), which is an activity that is provided by the company as a form of assistance or services in the routine life of the employee as a recreational activity, cafeteria to serve food and drink for employees, employee housing, scholarships, counseling, financial and legal as well as a variety of other services. Forth, the compensation payments are set legally the granting of compensation to employees who have been defined by the Act, such as the provision of compensation to employees who suffer from disabilities (and not able to work again) because of an accident at work, the provision of severance pay for employees who terminated their employment relationship, payment employment insurance and health care on a periodic basis where it is set up by the government in the Law on safety issued on January 12, 1970. Fifth, employee safety and health. Companies pay attention to this to provide safer and healthier working conditions, and become more responsible for employee activities, especially organizations that have high accident rates. This requires handling by a specialist, so that many large companies have security personnel and doctors in the company to manage the health of employees in the organization. Employee safety and health programs that can be carried out are: making working conditions safe by completing safety equipment on 
existing machines in the company, managing the company layout as best as possible, carrying out maintenance of facilities as possible and making instructions on security equipment. Besides accident prevention activities can also be done by giving strict restrictions such as not smoking to the company and making messages to keep reminding about the safety of the company. The creation of a healthy environment to maintain the health of employees can also be done by regulating lighting at work, regulating humidity and air temperature, maintaining environmental cleanliness, providing various facilities needed by employees such as bathrooms, changing rooms and others.

Mathis and Jackson (2006) suggests there are several indicators used to assess the compensation received by employees, namely salaries or wages, bonus, health insurance, the period of vacation or furlough, compensation works. According to Allen and Grisaffe (2001) employee loyalty is a psychological state that illustrate the relationship between the employee and the organization that will affect the employees to remain with organization. Employees loyalty can also be seen as unpleasent strong attachment to the organization as part of an emotional response, because Together desire to members of an organization. The desire was driven by a strong belief in the goals and values that exist in the organization (Wu and Norman, 2006).

Loyal members of an organization are willing to put a lot of effort in the betterment of the organization (Yao, Qiu and Wei,
2019). So, the major element of loyalty is the employees' belief in the values of the organization and hence, they have a strong desire to be with the organization. An employee who is loyal to the organization works harder at the workplace to achieve the goals that have been set by the organization. This is an important factor that retains the employee in the organization (Farrukh et al., 2019). From the above understanding, the conclusion is a tendency of employees to move to another company. If the employee works in a company, and the company has provided adequate facilities and received by employees, the loyalty of employees will increase in the company and there is a push to make employees work harder.

Employee loyalty towards the organization has meaning willingness to perpetuate a relationship with the organization, if necessary by sacrificing his personal interests in order to achieve success and the success of the organization. Willingness of employees to defend themselves working within the company are important in supporting employee commitment to the organization in which they work. This can be pursued when employees feel their security and satisfaction within the company. So, the main element of loyalty is employees trust to organizational values which led to a strong desire for the Joint organization.

Various facilities provided by the company so that employees can work as good as possible and remain loyal to the company according to Nitisemito (1991) namely enough salary, providing spiritual needs, creating a relaxed atmosphere, 
placing the employee in the right position, giving employees the opportunity to advance, noting security to employees to face the future, inviting employees to negotiate, providing a pleasant facility. An important role for human resources management to manage employees through various policies, one of which is the implementation of the compensation program administration. The source of dissatisfaction can be both material and non-material, dissatisfaction materially received in the form of low wages, minimum facilities. As for dissatisfaction in a non-material form of lack of respect as a human being, not to participate in activities in the company and so on.

Loyalty is not formed just working in a company, but there are aspects that can create job loyalty. According to Steers and Porter (1983) aspects of loyalty-related attitudes that will do employees and the creation of loyalty psychological processes work within the company, among others are: First, a strong urge to remain a member of the company. The strength of this aspect is strongly influenced by individual circumstances such as the need, purpose and suitability of the company. Second, the desire to try as much as possible for the company. A shared understanding between employees and the company and supported by the same goal so it appears a strong desire to try its utmost. Third, definite confidence and full acceptance of the values of the company. Created employee trust cannot be separated because of the trust the company to the employee to carry out and complete the job.
Other aspects of loyalty by Siswanto (2003), which focuses on the implementation of the work the employee is: First, obey the rules. Employees have the ability to comply with all regulations, orders in the company and does not violate the prohibition contained in written and unwritten. Increased obedience by employment is a key priority in the development of labor in order to increase employment in the company's loyalty. Second, responsible. Ability of employees to perform their jobs well and will awareness risk of performing the task will give a sense of the courage and willingness to assume responsibility, so there would be job loyalty. In other words, employees who have a high loyalty then the employee has the responsibility for good work. Third, work attitude. Employees who have a high loyalty it will have a positive work attitude. Positive work attitude as the willingness of employees to work together, have a sense of belonging to the company that comes a sense of responsibility, have a social relationship between employees well and loved her job.

According to Budi Widjaja Soejipto in Saydam (2000) one of the causes of low employee loyalty is a compensation system that does not guarantee job peace in the form of indirect payments or benefits such as pensioners and health insurance. In the research of The Canadian bar association survey (2012), it is stated that employee satisfaction is very much determined by the level of benefit package or what is commonly called indirect compensation. This is evidenced by the perceived satisfaction of the benefits package 
offer that is $>70 \%$, very effective so that loyalty of employees increases and the level of employee turnover is very low.

So the hypothesis of this study are, $\mathrm{H} 1$ : resting on the job, protection against danger, service programs, legal and health insurance payments is the dimension of indirect compensation. H2: Indirect payment significantly influence employee loyalty at Bank Perkreditan Rakyat (BPR) Sadyha Mukti Parama office.

\section{RESEARCH METHOD}

This research was a quantitative research, with survey methods and questionnaire providing a set of questions or a written statement to the respondent to answer as the research tools. The object of this study is the employees of BPR Sadyha Mukti Parama, because Bank Perkreditan Rakyat (BPR) is one of the important backbone of national development. The population and sample in this study were 16 employees of BPR Sadyha Mukti Parama questionnaires. The data analysis method was SEM (structural equation model) PLS (Patial Least Square).

\section{RESULTS AND DISCUSSION}

Evaluation of convergent validity is done by looking at the value of the loading factor of each indicator. Loading factor greater than 0.5 indicates that the indicators were valid convergent. Compensation variable loading factor Time Not Working vary from 0606 until 0859 which means that the indicators forming the variable compensation for time off in this study is valid. As for the Protection Against Hazards variable has a loading factor varies between 0945 to 0955 , which means that the variable is formed by the Protection Against Hazards valid indicators. Likewise, with Care Program variables have factor loading values varying between 0640 and 0960. Variable Compensation Required Legal has valid values between 0.93 and 0961 .

In addition to showing the value of factor loading for each construct, convergent validity may also be indicated by using the value of Average Variance Extracted (AVE). According to Hair et al. (2011), a value greater than 0.5 AVE (AVE> $0.5)$ indicate that there are problems of convergent validity. Looks of statistical tests that value AVE of each construct was above 0.5 . Therefore it can be said that there are problems related to the convergent validity as in Table 1.

\section{Table 1. Values AVE}

\begin{tabular}{lc}
\hline & AVE \\
\hline Compensation Time Not & $0: 50$ \\
Working & \\
Employee Health & 0.88 \\
Compensation Legal & 0.92 \\
Protection against Hazards & 0.91 \\
Program Service & 0.81 \\
Loyalty & 0.60 \\
\hline
\end{tabular}

Discriminant validity was evaluated through cross loading value. It appears from the results of testing by cross loading that value factor loading of each item measurement is greater than the value of cross loading. The measurement results showed that not found a problem related to the discriminant validity

Uni-dimensionality of the items measured by the value of composite reliability. Composite reliability is 
evaluated to determine whether each of the variables tested in a research model is reliable. Variables with composite reliability values greater than 0.7 are considered reliable. Based on Table 2, composite reliability values for each variable was considered reliable because it has a value of more than 0.7 .

Table 2. Value Composite Reliability

\begin{tabular}{lc}
\hline & AVE \\
\hline Compensation Time Not & 0.75 \\
Working & \\
Employee Health & 0.85 \\
Compensation Legal & 0.96 \\
Protection against Hazards & 0.97 \\
Program Service & 0.97 \\
Loyalty & 0.90 \\
\hline
\end{tabular}

After testing the outer models suggest that the indicators used to measure each variable is valid and reliable, the test was conducted to see the model inner diversity magnitude of data that can be explained by the model. Testing is done by looking at the inner model of the R-square value of endogenous variables. The greater the $\mathrm{R}$-square value the greater the $\mathrm{R}$ square value, it means that the stronger predictive power owned by the model. R-square value of each of the endogenous variables, can be calculated the value of the Q-square (Relevance predictive value) which describes how much predictive power possessed by the model. Q-square for the model of this study was $86 \%$, which means that the model can explain the diversity of the data by $86 \%$, while $14 \%$ is explained by other variables not included in the model

After testing the outer and inner models do and get results that satisfy both, further research hypothesis testing can be done. The first hypothesis formulated that break on the Job, protection against danger, service programs, payment of legal and health insurance is the dimension of indirect compensation from Figure 1 the antecedents of indirect compensation has a positive effect so variable Resting on the Job, Protection against, service programs, legal and health insurance payments is the dimension of indirect compensation. These results can be interpreted that the first hypothesis is accepted.

Hypothesis 2 suggest that the experiences have a significant impact on customer loyalty. The results of hypothesis testing shows that there is a significant positive effect of experience on consumer loyalty $(\mathrm{t}=$ 3.962: $\beta=3.615)$. The results of this test means that the more positive the experience perceived by consumers will make consumers more loyal to the direstoran dining. These test results mean Hypothesis 2 is accept.

Based on Figure 1 breaks on the job showed T-statistics at 24.13 (> 2.1). The original value estimate samples also showed 0.811 which means the relationship between a break on the job and loyalty is positive. After that variable protection against hazards to the loyalty demonstrated T-statistic of 70.19 (> 2.1). Orginal value estimate samples also showed 0.910 which shows that the direction of a positive relationship.

The next variable is service programs with demonstrated loyalty T-statistic of 153.54 (> 2.1). Orginal value estimate sample showed positive numbers is equal to 0,960 . On the relationship between legal payment and loyalty demonstrated by 
T-statistically significant amounted to 90.86 (> 2.1). The value of the original sample is also positive estimate 0.927 which showed also a positive relationship. The results of the last test with the health insurance is a significant loyalty with T-statistic of 42.714 (> 2.1). Value estimate the original sample showed 0.875 which indicates that the relationship is also positive. Based on the entire value of the original estimate of the obtained results that the service programs showed a value of 0,960 where it shows that the programs have an influence on Loyalty Services is higher than other types of compensation Indirect others. While resting on the job showed a small value that is equal to 0.811 .

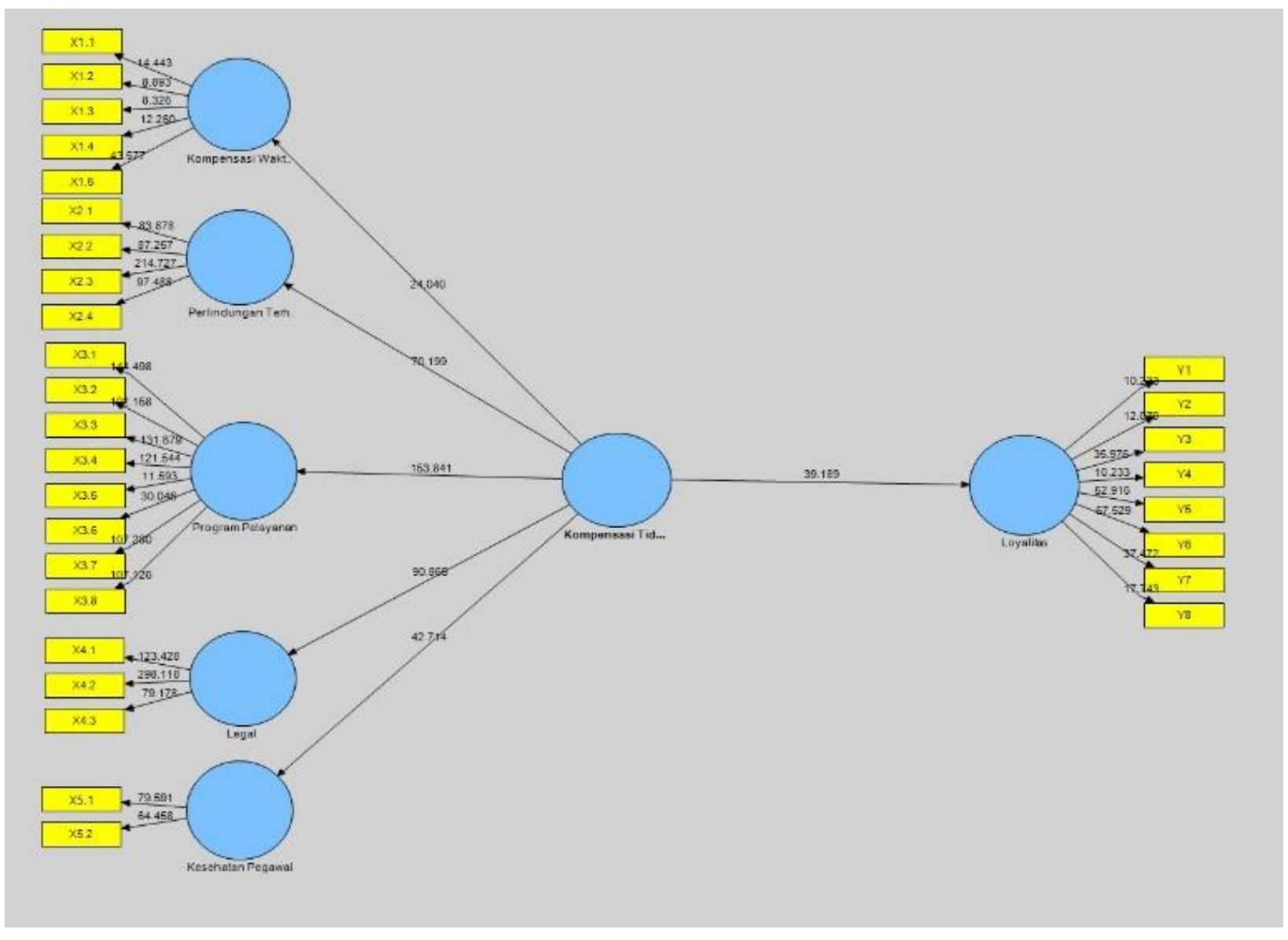

Figure 1. Hypotehesis Testing Results

The first and second hypothesis stating indirect compensation effect on employee loyalty is accepted. The results of this study are in accordance with the study Kasper, et al. (2012) which states that the compensation does not directly affect the employee loyalty. Based on the analysis of data in this study show that the compensation indirect positive effect on employee loyalty. Substantially the results showed that the strongest indicator that supports variable indirect compensation to the loyalty of the employees are the programs of the employees. 
The programs of employees in the opinion of the respondents is paramount, this is because employees of Bank Perkreditan Rakyat (BPR) Sadyha Mukti Parama already find facilities such as a break on the Job, protection against danger, service programs, payment of legal and health insurance was considered enough to meet the needs. Based on this research shows that for onedimensional variable indirect compensation that is resting on the job has a value small enough that it could more attention to this dimension.

\section{CONCLUSIONS}

This study provides some theoretical implications indicate that the compensation does not directly provide a significant impact on employee loyalty Bank Perkreditan Rakyat (BPR) Sadyha Parama Mukti. With the positive influence the Bank Perkreditan Rakyat (BPR) Sadyha Mukti Parama can consider carefully the compensation is due greatly impact on loyalty. It is also of the results showed that the dimension of indirect compensation that is variable

\section{REFERENCES}

Allen, N. J. and Grisaffe, D. B., 2001, 'Employee commitment to the organization and customer reactions: Mapping the linkages', Human Resource Management Review. Elsevier, 11(3), pp. 209236.

Dessler, Gary., 2006, Manajemen Sumber Daya Manusia, Edisi ke10 Jilid 1 Indeks, Klaten.

Farrukh, M., Kalimuthuan, R., \& Farrukh, S., 2019. Impact of Job Satisfaction and Mutual Trust on break on the job, protection against danger, service programs, legal and health insurance payments significant effect on employee loyalty. Bank Perkreditan Rakyat (BPR) Sadyha Mukti Parama also have to consider the dimensions of the above variables can be changed and will continue to undergo changes if the workforce owned by companies are increasingly varied. The compensation can be realized and adapted to existing circumstances.

Further research is expected to add variable employee performance, as closely related to compensation and loyalty to the performance of employees in a company so that research on these themes can develop. In addition, this study can also be developed associated with several dimensions owned by compensation, can be seen in the present are scaling many variables beyond the current one, such as a comfortable environment, coworkers who are supportive, as well as some other variable dimensions. Development of the age and the existing work force to compensate the company changed and more flexible

Employee Loyalty in Saudi
Hospitality Industry: A
Mediating Analysis of Leader
Support. International Journal of
Business and Psychology, 1(2),
30-52. Flippo, Edwin B., 2002, Personel Management (Manajemen Personalia), Edisi VII Jilid II, Terjemahan Alponso S, Erlangga, Jakarta.

Gouzali Saydam., 2000. Manajemen Sumber Daya Manusia (Human Resource) Suatu Pendekatan 
Mikro, Djanbatan, Jakarta.

Gunawan, Yogi T., 2007. Pengaruh Pemberian Kompensasi

Terhadap Loyalitas Kerja Karyawan (Studi Kasus Pada PT. Jaya Mekar Sari PPLitar), Fakultas Ekonomi dan Bisnis Universitas Brawijaya. Malang.

Handoko, T. Hani., 2010., Manajemen Sumber Daya Manusia, Fakultas Ekonomika dan bisnis Universitas Gajah Mada, Yogyakarta.

Hartono, Jogiyanto dan Abdillah, 2009, Konsep dan Aplikasi PLS, BPFE, Yogyakarta.

Hasibuan, Malayu., 2010., Organisasi dan Motivasi, Cetakan Ketujuh, Bumi Aksara,Jakarta.

Hasibuan, S. P Melayu. 2012. Manajemen Sumber Daya Manusia. Jakarta: Bumi Aksara.

Kasper, Helmut., Juergen Muehlbacher, Georg kodydek and Liping Zang., 2012, Fringe benefits and loyalty on the Chinese labour market-a trend towards higher individual and performance orientation, Journal of Technology Management in China, Vol. 7 No. 2, pp. 164-176.

Krisna, Maria., 2011, Pengaruh Kecerdasan Emosional Pemimpin Terhadap Kinerja dan Loyalitas Karyawan (Studi Kasus pada PT. Riau Andalan Pulp dan Paper Bisnis Unit Riau Fiber), Tesis Fakultas Ekonomi dan Bisnis Universitas Brawijaya. Malang.

Mathis, Robert L dan Jackson, John H., 2009, Manajemen Sumber Daya Manusia. Salemba Empat, Jakarta.

Mondy, R. Wayne, Robert M. Noe., 2002, Human Resource
Management, Prentice Hall Upper Saddle River, NJ,

Nitisemito, S. Alex., 1991, Manajemen Personalia : Manajemen Sumber Daya Manusia, Ghalia Indonesia, Jakarta Timur.

Notoatmodjo, Soekidjo. 2009. Pengembangan Sumber Daya Manusia. Jakarta: Rineka Cipta.

Poerwadarminta, WJS., 2002, Kamus Besar Bahasa Indonesia, Balai Pustaka, Jakarta.

Saydam, Gouzali., 2000, Manajemen Sumber Daya Manusia (Human Resources Management) : Suatu Pendekatan Mikro (Dalam Tanya Jawab), Djambatan, Jakarta.

Schuler, Randalls and Jackson E. Susan., 1997, Human Resource Management, New York, West Publishing Company.

Simamora, Henry. 2006. Manajemen Sumber Daya Manusia, edisi ketiga, Cetakan kedua, Yogyakarta: Penerbitan STIE YKPN.

Siswanto, Bejo., 2003, Manajemen Tenaga Kerja Indonesia Pendekatan Administratif Dan Operasional, PT Bumi Aksara, Jakarta.

Steers, R.M dan Porter, L. W., 1983, Motivational and Work Behavior, Mc Graw Hill Book Company, New York.

Sugiyono, 2007. Statistik Untuk Penelitian, Cetakan Keduabelas, Alfabeta,Bandung.

$\mathrm{Wu}, \mathrm{L}$. and Norman, I. J., 2006. 'An investigation of job satisfaction, organizational commitment and role conflict and ambiguity in a sample of Chinese undergraduate nursing students', Nurse education today. Elsevier, 26(4), pp. 304-314. 